\title{
Associations of postpartum lying time with culling, milk yield, cyclicity, and reproductive performance of lactating dairy cows
}

\author{
J. M. Piñeiro, ${ }^{1 *}$ B. T. Menichetti, ${ }^{1}$ A. A. Barragan, ${ }^{1} \dagger$ A. E. Relling, ${ }^{2}$ W. P. Weiss, ${ }^{2}$ S. Bas, ${ }^{1} \ddagger$ \\ and G. M. Schuenemann ${ }^{1} \S$ \\ ${ }^{1}$ Department of Veterinary Preventive Medicine, The Ohio State University, Columbus 43210 \\ ${ }^{2}$ Department of Animal Sciences, The Ohio State University, Wooster 44691
}

\section{ABSTRACT}

The objectives were to evaluate the associations of lying time (LT) during the first $14 \mathrm{~d}$ in milk (DIM) with milk yield, cyclicity (CYC), culling within 60 DIM (CULL), and reproductive performance of lactating dairy cows. A total of 1,052 Holstein cattle (401 nulliparous heifers and 651 parous cows) from 3 commercial dairy farms had electronic data loggers (IceQube, IceRobotics, Edinburgh, UK) placed on a hind leg $14 \pm$ $3 \mathrm{~d}$ before the expected parturition date and removed at $14 \pm 3$ DIM to assess their LT. Serum concentrations of $\beta$-hydroxybutyrate were determined at $7 \pm 3$ and 14 \pm 3 DIM. Cases of retained placenta, metritis, mastitis, pneumonia, and digestive disorders within 30 DIM were recorded and lactating cows were categorized into 1 of 4 groups: (1) nondiseased (ND, $\mathrm{n}=613$; cows without ketosis or any other diagnosed health condition); (2) cows with only ketosis (KET, $\mathrm{n}=152$ ); (3) sick cows experiencing $\geq 1$ health conditions but without ketosis (SICK, $\mathrm{n}=198$ ); or (4) cows with ketosis plus $\geq 1$ health condition $(\mathrm{KET}+, \mathrm{n}=61)$. Ultrasound was performed at $28 \pm 3$ and $42 \pm 3$ DIM to assess ovarian cyclicity (presence or absence of corpus luteum). Milk yield at first Dairy Herd Improvement Association test was not associated with LT during the first 14 DIM, but it was negatively correlated with the coefficient of variation of LT during the first 14 DIM. Lactating dairy cows experiencing KET + had the lowest milk yield compared with ND, regardless of parity. Parity, health status, and season were significantly associated with CYC and CULL. Lying time had a significantly

Received July 15, 2018.

Accepted December 22, 2018.

*Current address: Texas A\&M AgriLife Research and Extension Center, Amarillo 79106.

†Current address: Department of Veterinary and Biomedical Sciences, Pennsylvania State University, University Park 16802.

$\ddagger$ Current address: Phytobiotics Futterzusatzstoffe GmbH, D-65343 Eltville, Germany.

§Corresponding author: schuenemann.5@osu.edu linear association with the risk of being culled: for every 1-h increment of LT during 0 to 14 DIM, the risk of culling within 60 DIM increased by 1 percentage point. Lying time had a negative quadratic association with cyclicity at 42 DIM. Multiparous cows with a LT of 9 to $13 \mathrm{~h} / \mathrm{d}$ had a significantly greater probability of pregnancy up to 300 DIM compared with cows with a LT $>13 \mathrm{~h} / \mathrm{d}$. Regardless of parity, KET + cows had significantly higher proportion of culling within 60 DIM and decreased probability of pregnancy up to 300 DIM compared with ND cows. These findings suggest that there is an optimum daily LT range for early postpartum cows housed in freestall barns, different from that reported for mid-lactation cows, with the potential for improved survival, health, and the overall performance (milk yield and reproduction).

Key words: lying time, milk yield, reproduction, dairy cattle

\section{INTRODUCTION}

Health traits are important for improved fertility and longevity of dairy cows, which affect the profitability of dairy operations (Boichard, 1990; Essl, 1998). The annual culling rate (cows exiting herds because of slaughter, death, or sale; Fetrow et al., 2006) in the United States for the last 2 decades has been about 35 to $40 \%$, with a large number of cows exiting the herd early in lactation (De Vries, 2013). Excessive culling (e.g., >35\%) might increase replacement costs and reduce profitability of dairy herds (Schuenemann et al., 2017). Metabolic and infectious diseases (e.g., milk fever, metritis, mastitis) along with lameness and dystocia increase the risk of culling (Rajala-Schultz and Gröhn, 1999; Beaudeau et al., 2000). Death, injury, and diseases are the primary reasons for early removal of cows in early lactation (Pinedo and De Vries, 2010). Therefore, implementing a proactive preventive transition cow management will likely reduce the risk for diseases, with a subsequent reduction of culling during early lactation. 
Reduced lying time (LT) has been associated with increased lameness (Galindo and Broom, 2000). In turn, lameness reduces DMI and milk yield and increases the risk of culling and impaired cyclicity and reproductive performance (Beaudeau et al., 2000; Bach et al., 2007; Dubuc et al., 2011). In addition, cows prevented from lying down had decreased eating bouts and daily feeding time (Munksgaard and Simonsen, 1996; Huzzey et al., 2006), which could result in slug feeding and digestive disorders (Cooper et al., 2007; Schirmann et al., 2012). However, the association of LT with milk yield is controversial. Some authors suggested a positive correlation between milk yield and LT (Grant, 2007), whereas others have shown a negative correlation (Hasegawa et al., 1993; Fregonesi and Leaver, 2001; Norring et al., 2012) or no correlation at all (Steensels et al., 2012).

Herd-level factors affecting LT (Grant and Albright, 2001; Tucker et al., 2004; Drissler et al., 2005; von Keyserlingk et al., 2008; Krawczel et al., 2012; Allen et al., 2015), as well as cow-level factors affecting LT (Chapinal et al., 2009; Steensels et al., 2012; Maselyne et al., 2017) should be considered when evaluating the association of LT with milk yield. Research controlling confounders such as season, parity, and health events is needed to assess the association of LT with milk yield. In addition, the association of LT during the transition period with culling within 60 DIM, cyclicity, and reproductive performance has not been previously investigated. We hypothesized that reduced LT during the first 14 DIM would be associated with reduced milk yield at first DHIA test day, increased culling within 60 DIM, reduced cyclicity, and decreased probability of pregnancy of cows up to 300 DIM. Therefore, the objectives of this study were to assess the associations of LT during the first 14 DIM with milk yield at first DHIA test day, culling within 60 DIM, cyclicity, and reproductive performance of lactating dairy cows.

\section{MATERIALS AND METHODS}

\section{Animals and Facilities}

A total of 1,052 pregnant Holstein animals (401 nulliparous heifers, 278 primiparous and 373 multiparous cows) from 3 commercial dairies selected by convenience (housed cows in freestall barns) and located in central Ohio were used for this prospective observational study. Cohorts of 20 to 36 pregnant heifers and cows were enrolled for 2 consecutive weeks, at each farm, every 5 wk for a 1-yr period. Farms were visited twice weekly. At enrollment, a list of prepartum heifers and cows 2 wk before the expected calving date $(262 \pm 3 \mathrm{~d}$ of gestation; Vieira-Neto et al., 2017) was obtained using days pregnant from on-farm computer records (days carry calf; Dairy Comp 305, Valley Agricultural Software, Tulare, CA). A schematic representation showing the timeline for data collection relative to calving is provided in the companion paper (Piñeiro et al., 2019).

On farm 1, pregnant heifers and cows were grouped separately in different pens during the prepartum period and commingled in the same pen during the postpartum period, housed in a 4-row freestall barn with deep recycled manure bedding, and fed a TMR twice daily at 0700 and $1230 \mathrm{~h}$ during summer and once daily at $0700 \mathrm{~h}$ during the rest of the year. On farms 2 and 3, pregnant heifers and cows were grouped together (commingled) during the pre- and postpartum periods, housed in 6-row freestall barns with deep sand bedding, and fed a TMR once daily at $0900 \mathrm{~h}$. All farms grouped their animals at dry-off (60 to $22 \mathrm{~d}$ before calving), at prepartum (21 d before calving), and at postpartum (up to 21 DIM), and had high (22-150 DIM) and low (>150 DIM) milk yield pens for their lactating cows. In addition, pregnant animals in the prepartum pen were frequently monitored by on-farm personnel for imminent signs of parturition, at which time they were moved into contiguous maternity pens at calving. Dairy cattle were fed a TMR to meet or exceed dietary nutritional requirements (NRC, 2001). The ingredient and nutrient composition of formulated pre- and postpartum diets (DM basis) were reported by farm (provided in the companion paper; Piñeiro et al., 2019). On farms 1 (1,300 dairy cows) and 2 (1,500 dairy cows), cows were milked 3 times daily in double-20 parallel and double-24 herringbone parlors, respectively. On farm 3 (2,700 dairy cows), cows were milked cows 4 times daily during the early postpartum period in a double-32 parallel parlor. All farms used natural ventilation and had fans on their pens and holding area before the milking parlor for heat abatement. During the study period, the average daily milk yields per cow were 36,29 , and 35 $\mathrm{kg} / \mathrm{d}$ for farms 1,2 , and 3 , respectively.

Body condition score (5-point scale with 0.25-unit increments; Ferguson et al., 1994) and locomotion score $(\mathbf{L S}, 1=$ sound, $2=$ mildly lame, $3=$ moderately to severely lame; as described by Walker et al., 2008) were assessed at $-14 \pm 3,14 \pm 3$, and $28 \pm 3 \mathrm{~d}$ relative to calving. This study was conducted from August 2016 through February 2018. The procedures described below were reviewed and approved by The Ohio State University Institutional Animal Care Use Committee.

\section{Health Events, Milk Yield, Culling, Cyclicity, and Reproduction}

Data pertaining to diseases (retained placenta, mastitis, pneumonia, and digestive disorders) within the first 30 DIM, culling within 60 DIM (CULL; cows sold, 
slaughtered, or dead within 60 DIM), and reproductive performance (pregnancies up to 300 DIM) were obtained from on-farm records (DairyComp 305, Valley Agricultural Software). Farm personnel responsible for the health program received training by G. M. Schuenemann (on-farm workshop followed by hands-on demonstrations) on case definitions of health events and recording before the start of the study. Briefly, farm personnel performed a health screening of early postpartum cows (within the first $4 \mathrm{wk}$ after calving) every morning after the first milking. Clinical examination included changes in milk yield (first morning milking), assessment of vaginal discharge, presence of fetal membranes outside the vulva, and signs of dehydration such as sunken eyes, attitude, and rumen fill. Lactating cows experiencing any observed sign of illness such as a sudden drop in milk yield or abnormal vaginal discharge were subject to a thorough hands-on examination (assessment of rectal temperature, rectal palpation, and abdominal and thoracic auscultation and percussion). Retained fetal membranes was defined as the failure to expel fetal membranes $24 \mathrm{~h}$ after calving. Left displaced abomasum was defined as the translocation of the abomasum to an abnormal position on the left side of the abdomen characterized by a "ping" sound at auscultation while performing digital percussion. All cows were examined at $7 \pm 3$ DIM for metritis by the research team. Metritis was defined as a fetid, watery, red-brown uterine discharge with or without pyrexia (Sheldon et al., 2006). Lactating cows experiencing cases of clinical mastitis (abnormal milk secretion with presence of flakes or clots with or without swollen udder) were identified by farm milkers during the milking routine.

Blood samples were obtained from all heifers and cows for determination of BHB at $7 \pm 3$ and $14 \pm$ 3 DIM after calving, respectively. Cows having serum concentrations of $\mathrm{BHB} \geq 1.2 \mathrm{mmol} / \mathrm{L}$ from at least one blood sample $(7 \pm 3$ or $14 \pm 3$ DIM) were classified as having ketosis. Blood samples were collected via coccygeal venipuncture using $8-\mathrm{mL}$ evacuated tubes by 2 members of the research team (J. M. Piñeiro and B. T. Menichetti) and farm personnel. To control the confounding effect of health status when assessing the association of LT with culling, cyclicity, milk yield, and reproduction, lactating dairy cows were classified into 1 of 4 groups with regards to their health status, as described in the companion paper (Piñeiro et al., 2019): (1) nondiseased (cows without ketosis or any other diagnosed health conditions; ND, $\mathrm{n}=613$ ); (2) cows diagnosed with only ketosis (KET, $\mathrm{n}=152$ ); (3) cows experiencing $\geq 1$ health conditions, but without ketosis (SICK, $\mathrm{n}=198$ ); or (4) cows with KET plus at least 1 health condition $(\mathbf{K E T}+, \mathrm{n}=61)$. Prepartum or postpartum LS were not included in the criteria to classify the health status of postpartum cows.

Data pertaining to milk yield $(\mathrm{kg} / \mathrm{d})$ from the first monthly DHIA test were obtained from on-farm records for farms 1 and 3 (DairyComp 305, Valley Agricultural Software, Tulare, CA). Because farm 2 was not enrolled in DHIA, individual daily milk weights $(\mathrm{kg} / \mathrm{d})$ were recorded, and the average milk weights from 15 to 21 DIM after calving were obtained. The average DHIA test day of farms 1 and 3 was 18 DIM. Therefore, we chose to use an average milk yield from 15 to 21 DIM (18 \pm 3 DIM) because the estimate would be more precise than only using the 18 DIM value, which would be subject to daily variation. Transrectal ultrasound was performed on cows at $28 \pm 3$ and $42 \pm 3$ DIM to assess ovarian structures [presence or absence of a corpus luteum (CL)]. Lactating cows having a CL at $28 \pm 3,42 \pm 3$ DIM or both were classified as cycling (CYC). Only cows without a CL at both $28 \pm 3$ and 42 \pm 3 DIMwere classified as noncycling. Data for health events, milk yield, CULL, CYC, and reproductive performance were exported into an Excel spreadsheet (Microsoft Corp., Redmond, WA) for further analyses.

\section{Assessment of LT}

Electronic data loggers (IceQube, IceRobotics, Edinburgh, UK) were placed on a hind leg of prepartum heifers and cows at $14 \mathrm{~d}$ before calving and removed $14 \pm 3$ DIM to assess their behavioral activity. Data from individual animals were exported from IceManager software to an Excel spreadsheet. Lying time data were summarized and reported daily $(\mathrm{min} / \mathrm{d}$ or $\mathrm{h} / \mathrm{d})$. For each individual lactating cow, the overall mean and standard deviation of daily LT during the first 14 DIM was computed. Then, the coefficient of variation $(\mathbf{C V})$ was obtained as the ratio of the standard deviation to the LT mean and reported as an absolute value.

\section{Statistical Analyses}

Data pertaining to individual animals (e.g., parity, health events, and parturition date) were exported from DairyComp 305 into an Excel spreadsheet. Before data analyses, dairy cows that met the exclusion criteria (sold or died before the first clinical examination or did not calve during the study period because of incorrectly recorded conception date or abortion) were removed from the analyses.

Association of LT and Health Status with Milk Yield. The associations of daily LT during 0 to 14 DIM and health status (KET, KET+, SICK, and ND) with milk yield $(\mathrm{kg} / \mathrm{d})$ at first DHIA test were analyzed us- 
ing mixed linear regression models (MIXED procedures of SAS; SAS Institute, 2014). Milk yield was considered the outcome variable, and the predictor variables offered to the model included lying time, health status, parity, BCS and LS at enrollment, DIM at first DHIA test, season (fall, winter, spring, summer), health status (KET, KET+, SICK, and ND) within 30 DIM, LT during 0 to 14 DIM, as well as the interactions of parity $\times$ health status and parity $\times$ LT during 0 to 14 DIM. Nonsignificant variables were eliminated manually from the model one at a time using the Wald statistic backward selection criterion $(P>0.15)$ because of their lack of effect on the outcome variable. Because LT during 0 to 14 DIM was the predictor variable of interest, it was forced in the model regardless of significance. The final model included milk yield as the dependent variable, and LT during 0 to 14 DIM, health status, DIM at first DHIA test, and season as independent variables. Herd was included as a random effect and DIM at first DHIA test as a covariate. The differences in least squares means (LSM) were computed by including the PDIFF option in the LSMEANS statement. Mean comparisons were carried out using the Tukey-Kramer method. In addition, partial correlations between mean LT during 0 to 14 DIM (min/d) and milk yield $(\mathrm{kg} / \mathrm{d})$ at first DHIA test as well as between the coefficients of variation $(\mathbf{C V})$ of daily LT during 0 to 14 DIM and milk yield at first DHIA test were performed using the Pearson correlation coefficients (PROC CORR procedure of SAS; SAS Institute, 2014). Correlations were adjusted by parity, season, health status, BCS and LS at enrollment, and DIM at first DHIA test using the PARTIAL statement.

Association of LT and Health Status with CULL or $C Y C$. The association of LT and health (KET, KET+, SICK, and ND) with CULL and CYC were analyzed using logistic regression analyses (GLIMMIX procedures of SAS; SAS Institute, 2014). For the analysis, the mean LT during 0 to 14 DIM was grouped by hour intervals (e.g., cows with a mean LT between 480 and $540 \mathrm{~min} / \mathrm{d}$ were grouped together and then reported as $8 \mathrm{~h} / \mathrm{d}$ interval). Cows with mean $\mathrm{LT}<8$ $\mathrm{h} / \mathrm{d}$ or $>16 \mathrm{~h} / \mathrm{d}$ were coded as $<8$ and $>16 \mathrm{~h} / \mathrm{d}$, respectively. For each outcome of interest (CULL and CYC), models included parity (lactations 1, 2, 3, 4, 5, 6, or $\geq 7$, BCS and LS at enrollment, season, health status, and mean LT during 0 to 14 DIM as predictor variables. Nonsignificant variables were eliminated from the model one at a time using the Wald statistic backward selection criterion $(P>0.15)$. Herd was included as a random effect. The final models for each outcome of interest (CULL and CYC) included the effect of parity, health status, and season to obtain the adjusted LSM $( \pm$ SEM $)$. Using this model, a linear and quadratic
$(\mathrm{LT} \times \mathrm{LT})$ association of LT during 0 to 14 DIM with each outcome of interest was assessed. The differences in LSM of fixed categorical variables were computed by including the PDIFF option in the LSMEANS statement. Mean comparisons were carried out using the Tukey-Kramer method. Least squares means and standard errors of the means (SEM) are reported. A $P<$ 0.05 was considered statistically significant.

Association of LT and Health Status with Pregnancy. The associations of LT and health status with time to pregnancy up to 300 DIM were assessed using regression analysis of survival data based on the Cox proportional hazards models (PHREG procedures of SAS; SAS Institute, 2014). Primiparous (lactation $=1$ ) cows were divided in 3 different groups using the mean LT during 0 to $14 \mathrm{DIM} \pm 1 \mathrm{SD}$ of ND cows as referent values: $<8 \mathrm{~h} / \mathrm{d}, 8$ to $11 \mathrm{~h} / \mathrm{d}$ (reference values for primiparous cows), or $>11 \mathrm{~h} / \mathrm{d}$. Similarly, the LT during 0 to 14 DIM of multiparous cows (lactation $\geq$ 2 ) were grouped into 3 time intervals using the mean $\mathrm{LT} \pm 1 \mathrm{SD}$ of ND cows as referent values: cows lying $<9 \mathrm{~h} / \mathrm{d}, 9$ to $13 \mathrm{~h} / \mathrm{d}$ (reference values for multiparous cows), or $>13 \mathrm{~h} / \mathrm{d}$. Cox proportional hazard models were used to assess the association of LT during 0 to 14 DIM and health status with time to pregnancy up to 300 DIM, controlling for the effects of season, parity, and LS and BCS at enrollment, if significant. Herd was included in the STRATA statement to account for clustering effects. Data obtained from SAS output were exported into Excel and plotted to graph the proportion of cows pregnant over time. A $P<0.05$ was considered statistically significant and a $P \leq 0.10$ was considered a tendency to differ.

\section{RESULTS}

A total of 1,024 Holstein heifers and cows were included in the final analyses. Twenty-eight cows were excluded from the study [3 cows did not calve during the study period because of abortion or wrong conception date, and 25 cows were sold $(\mathrm{n}=9)$ or died $(\mathrm{n}=$ 16) before the first health screening at $7 \pm 3$ DIM]. Because dams were enrolled weekly $( \pm 3 \mathrm{~d})$, only $9.8 \%$ of dams out of 1,024 animals used in the study had 1 to 2 $\mathrm{d}$ of missing data due to calving earlier than expected. The distribution of heifers and cows by parity, season, and health status is available in the companion paper (Piñeiro et al., 2019).

\section{Associations of LT and Health Status with Milk Yield}

Mean LT for the first 14 DIM after calving did not have a significant effect on milk yield at first DHIA test (Table 1). Overall, there was no significant cor- 
relation between mean LT during 0 to 14 DIM and milk yield at first DHIA test, but there was a weak negative correlation between the CV of LT during 0 to 14 DIM and milk yield at first DHIA test $(\mathrm{r}=-0.16 ; P$ $<0.0001$, Figure 1). Season had a significant effect on milk yield at first DHIA test on multiparous cows $(P$ $=0.01$ ) and presented a tendency for primiparous cows $(P=0.06$, Table 1$)$. During winter, multiparous cows had significantly greater milk yield at first DHIA test compared with during summer and fall. Health status had a significant effect on milk yield at first DHIA test (Table 1). Regardless of parity, ND cows produced more milk at first DHIA test compared with KET+ cows. In addition, primiparous ND and KET cows produced significantly more milk at first DHIA test than KET+ and SICK cows.

\section{Associations of LT and Health Status with Culling}

The final model included the effect of LT during 0 to 14 DIM, health status, and parity as predictor variables. Lying time during 0 to 14 DIM had a significant linear association with CULL $(P=0.02$; Figure 2$)$. For

Table 1. Association of lying time (LT), season, and health status with milk yield $(\mathrm{kg} / \mathrm{d})$ at first DHIA test

\begin{tabular}{lcc}
\hline & \multicolumn{2}{c}{$\begin{array}{c}\text { Milk yield at first } \\
\text { DHIA test }(\mathrm{kg} / \mathrm{d})\end{array}$} \\
\cline { 2 - 3 } Variable $^{1}$ & Primiparous & Multiparous \\
\hline Mean LT, 0-14 DIM (h/d) & $31.4 \pm 3.50$ & $37.5 \pm 2.24$ \\
$<8$ & $28.8 \pm 3.53$ & $36.5 \pm 2.22$ \\
$8-8.9$ & $28.7 \pm 3.47$ & $39.7 \pm 2.02$ \\
$9-9.9$ & $29.3 \pm 3.50$ & $36.9 \pm 1.80$ \\
$10-10.9$ & $31.5 \pm 4.07$ & $37.9 \pm 1.75$ \\
$11-11.9$ & $24.4 \pm 4.77$ & $38.0 \pm 1.81$ \\
$12-12.9$ & $33.8 \pm 7.33$ & $36.4 \pm 2.02$ \\
$13-13.9$ & $29.1 \pm 9.85$ & $38.3 \pm 2.24$ \\
$14-14.9$ & 0.30 & $32.7 \pm 2.76$ \\
$>15$ & & 0.36 \\
$P$-value & $28.2 \pm 2.12$ & $36.3 \pm 1.77^{\mathrm{b}}$ \\
Season & $31.2 \pm 2.13$ & $39.5 \pm 1.73^{\mathrm{a}}$ \\
Fall & $31.4 \pm 2.10$ & $36.9 \pm 1.70^{\mathrm{ab}}$ \\
Winter & $28.0 \pm 2.18$ & $35.9 \pm 1.79^{\mathrm{b}}$ \\
Spring & 0.06 & 0.01 \\
Summer & & \\
$P$-value & $29.9 \pm 1.96^{\mathrm{a}}$ & $40.0 \pm 1.58^{\mathrm{a}}$ \\
Health status & & \\
ND & $32.6 \pm 2.55^{\mathrm{a}}$ & $38.3 \pm 1.75^{\mathrm{ab}}$ \\
KET & $22.0 \pm 2.79^{\mathrm{b}}$ & $33.5 \pm 2.21^{\mathrm{b}}$ \\
KET+ & $26.8 \pm 2.03^{\mathrm{b}}$ & $36.6 \pm 1.90^{\mathrm{ab}}$ \\
SICK & $<0.0001$ & 0.0005 \\
$P$-value & & \\
\hline
\end{tabular}

${ }^{\mathrm{a}, \mathrm{b}}$ Means within the same column with different superscript letters are significantly different.

${ }^{1}$ Least squares means $( \pm$ SEM) are presented.

${ }^{2} \mathrm{ND}=$ nondiseased cows; KET $=$ cows that experienced only ketosis; $\mathrm{KET}+=$ cows that experienced ketosis and at least another health condition within 30 DIM; and SICK = cows experiencing any disease other than ketosis during the study period. every 1 -h increment in LT during the first 14 DIM, the percentage of cows culled within 60 DIM increased by 1 percentage point. In addition, heath status had a significant effect on CULL $(P<0.0001$; Table 2). Nondiseased cows had a lower proportion of cows culled within 60 DIM compared with KET, KET+, and SICK cows (Table 2). Parity had a significant effect on CULL $(P=0.04$; Table 2$)$; lactating dairy cows in lactation $\geq 7$ had increased CULL compared with cows in earlier lactations (Table 2). Season did not have a significant effect on CULL $(P=0.14)$.

\section{Associations of LT and Health Status with Cyclicity}

The final model included the effect of LT during the first 14 DIM, health status, season, and parity as predictor variables. Lying time during 0 to 14 DIM did not present a significant linear association with CYC $(P=$ 0.43 ) but had a significant negative quadratic association on CYC $(P=0.01$; Figure 3$)$. In addition, KET+ cows tended to have a significant lower proportion of cows cycling by 42 DIM compared with ND $(P=0.06)$ and KET cows $(P=0.063$; Table 2$)$. Season had a significant effect on CYC $(P<0.0001)$. A greater proportion of lactating cows were cycling during summer and fall compared with winter and spring (Table 2).

\section{Associations of LT and Health Status with Pregnancy}

Lying time during the first 14 DIM of primiparous cows did not have a significant effect on time to pregnancy up to 300 DIM $(P=0.62$; Figure 4$)$. However, multiparous cows with an LT of 9 to $13 \mathrm{~h} / \mathrm{d}$ had a significantly increased probability of pregnancy compared with cows lying $>13 \mathrm{~h} / \mathrm{d}(P=0.03$; Figure 5$)$. Regardless of parity, KET+ and SICK cows had a significantly increased time to pregnancy up to 300 DIM compared with ND cows $(P<0.05$; Figures 6 and 7$)$.

\section{DISCUSSION}

The primary findings of the study, which differ from what we hypothesized, are as follows. (1) Milk yield at first DHIA test was not associated with LT during the first 14 DIM but was negatively correlated with the CV of LT during 0 to 14 DIM. (2) For every 1-h increment of LT during 0 to 14 DIM (from 8 to $15 \mathrm{~h} / \mathrm{d}$ ), the risk of culling within 60 DIM increased by 1 percentage point. (3) Lying time during the first 14 DIM had a negative quadratic association with cyclicity at 42 DIM. (4) Multiparous cows with mean LT of 9 to 13 $\mathrm{h} / \mathrm{d}$ during the first 14 DIM had a significantly greater probability of pregnancy up to 300 DIM compared 


\section{Partial Residual Scatter Plot}

With 95\% Prediction Ellipse

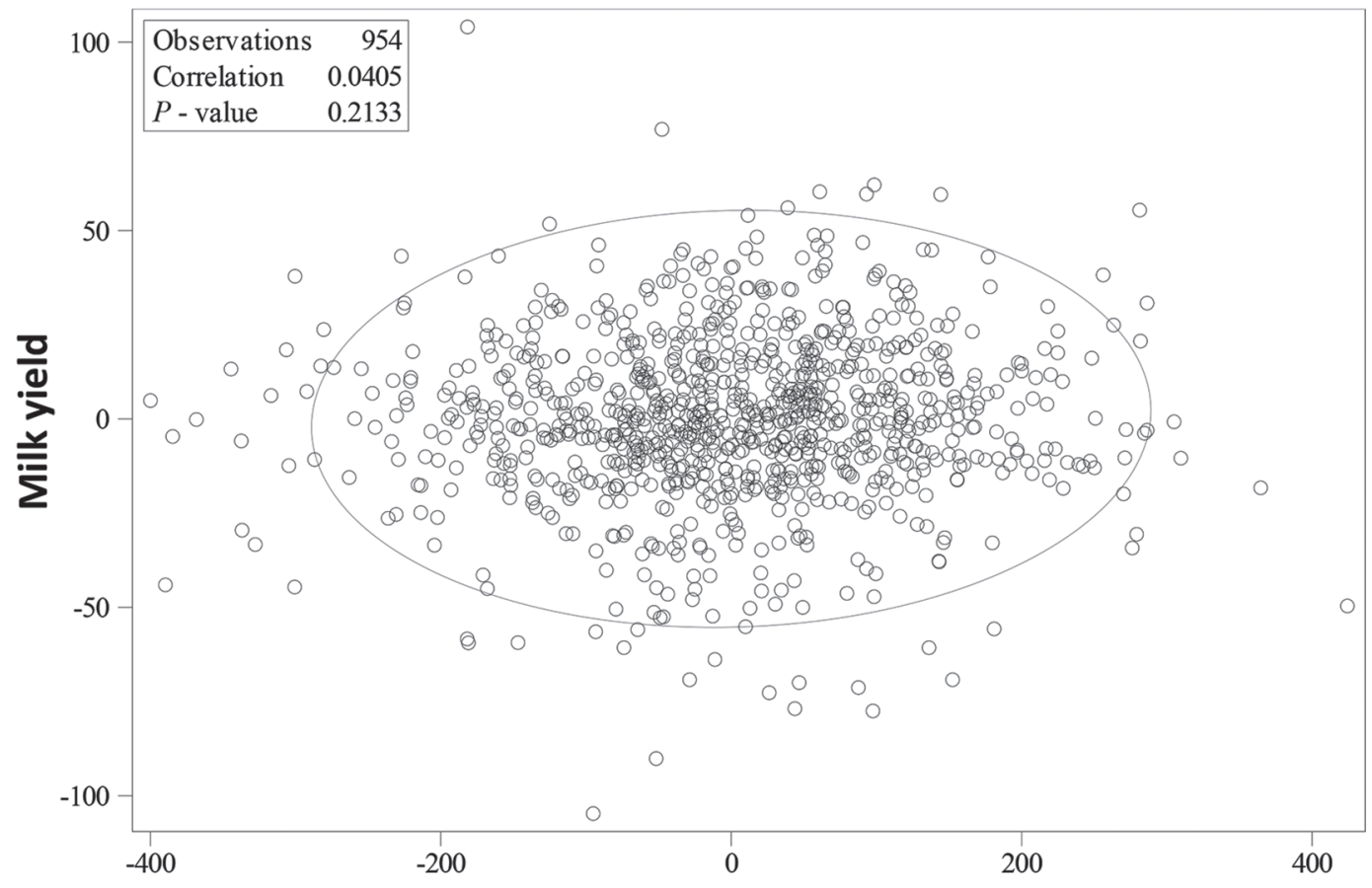

Mean lying time from 0 to 14 DIM

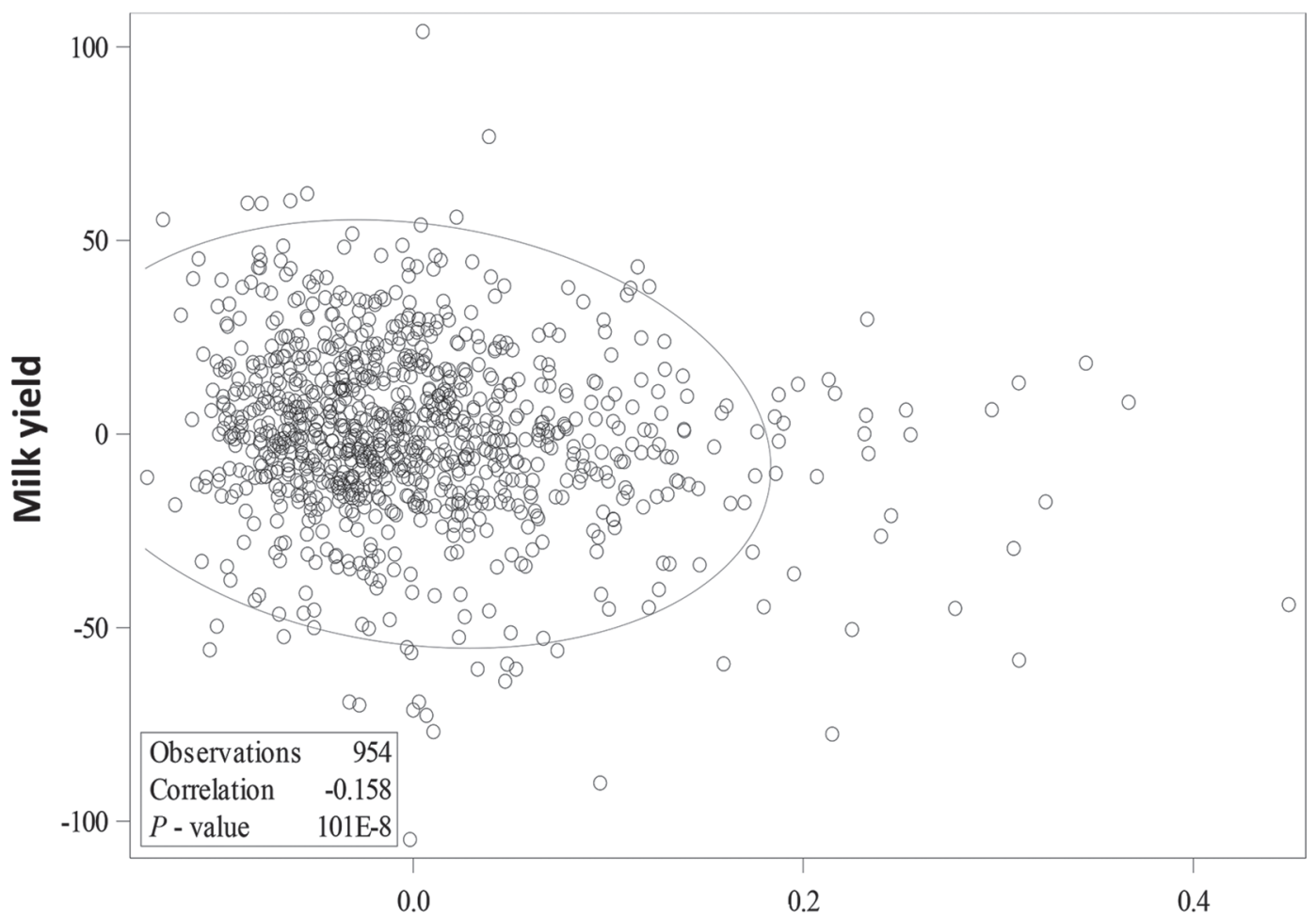

CV of lying time from 0 to 14 DIM

Figure 1. Partial correlations of milk yield at first DHIA test and mean lying time or coefficient of variation (CV) of lying time during 0 to 14 DIM for all cows adjusted by parity, season, health status, DIM at first DHIA test, and BCS and locomotion score at enrollment. 


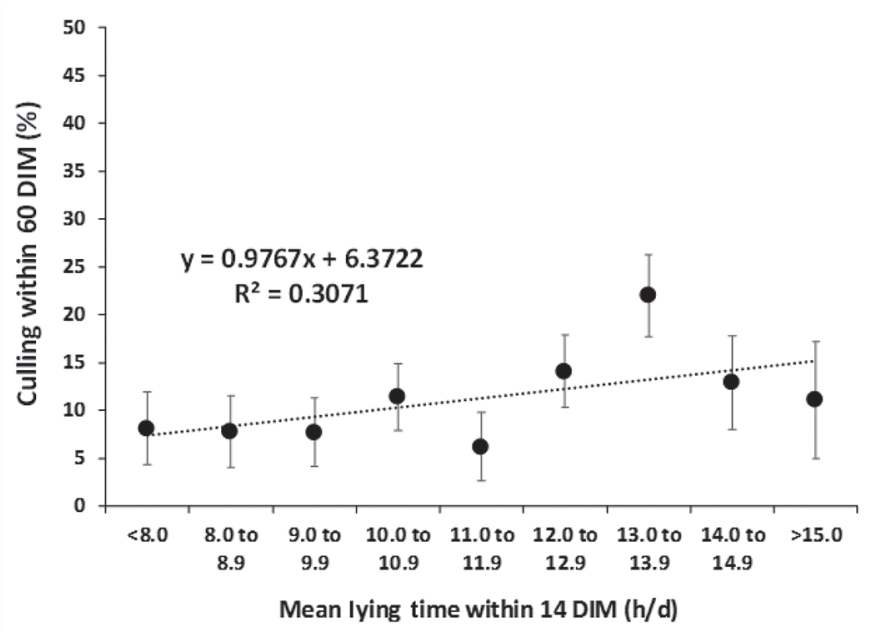

Figure 2. Association of culling within 60 DIM with lying time (LT) of lactating Holstein cows during 0 to 14 DIM grouped by hour intervals. The LSM of the proportion of cows culled by mean LT during 0 to 14 DIM grouped by hour intervals were obtained from the model and exported to an Excel file (Microsoft Corp., Redmond, WA) to show the significant linear association $(P=0.02)$. The LSM $( \pm \mathrm{SEM})$ of LT by hour intervals were obtained from the final model and plotted against culling within 60 DIM.

with cows with LT $>13 \mathrm{~h} /$ d. (5) Lactating dairy cows experiencing KET + had the lowest milk yield at first DHIA, the highest risk of being culled within 60 DIM,

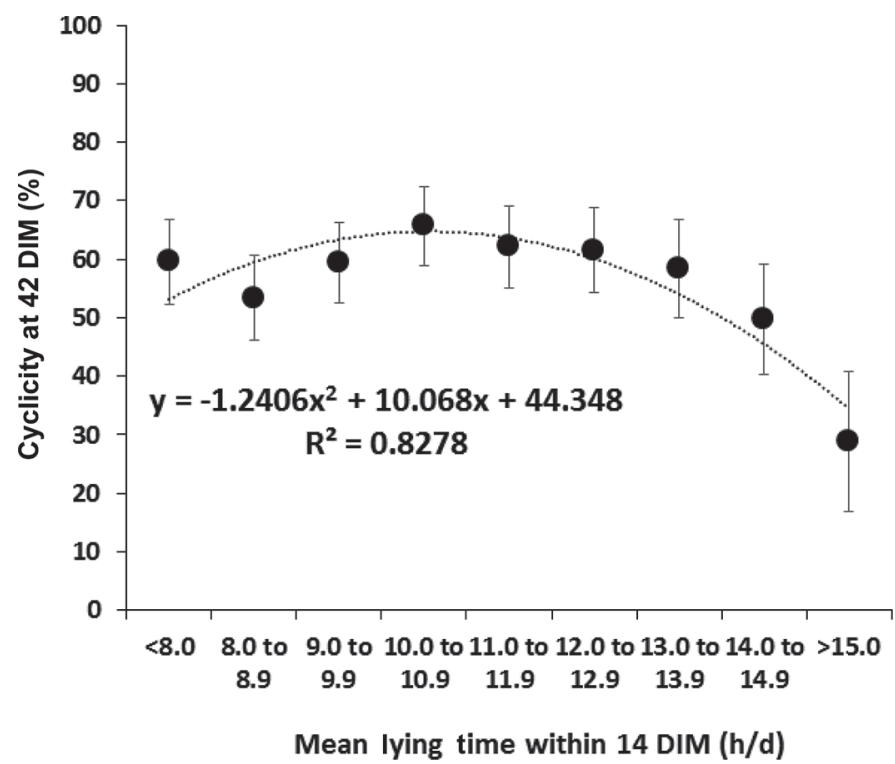

Figure 3. Association of cyclicity at 42 DIM with lying time (LT) of lactating Holstein cows during 0 to 14 DIM grouped by hour intervals. The LSM of the proportion of cows cycling by mean LT during 0 to 14 DIM grouped by hour intervals were obtained from the model and exported to an Excel file (Microsoft Corp., Redmond, WA) to show the significant quadratic association $(P=0.01)$. Cyclicity at 42 DIM was defined as the presence of a corpus luteum by ultrasound at $28 \pm 3$ or $42 \pm 3$ DIM. The LSM ( \pm SEM) of LT by hour intervals were obtained from the final model and plotted against cyclicity at 42 DIM.
Table 2. Association of culling within 60 DIM and cyclicity at 42 DIM with parity, season, and health status

\begin{tabular}{lcc}
\hline & $\begin{array}{c}\text { Culling within } \\
60 \text { DIM }\end{array}$ & $\begin{array}{c}\text { Cyclicity at } \\
\text { Variable }\end{array}$ \\
\hline Parity & \\
1 & & \\
2 & $9.5 \pm 3.21^{\mathrm{b}}$ & $50.0 \pm 6.73^{\mathrm{b}}$ \\
3 & $10.8 \pm 3.30^{\mathrm{b}}$ & $70.2 \pm 6.92^{\mathrm{a}}$ \\
4 & $9.5 \pm 3.34^{\mathrm{b}}$ & $67.1 \pm 7.19^{\mathrm{a}}$ \\
5 & $11.8 \pm 3.74^{\mathrm{b}}$ & $72.2 \pm 7.72^{\mathrm{a}}$ \\
6 & $9.2 \pm 4.69^{\mathrm{b}}$ & $60.2 \pm 9.37^{\mathrm{ab}}$ \\
$\geq 7$ & $7.1 \pm 5.91^{\mathrm{b}}$ & $76.5 \pm 11.52^{\mathrm{ab}}$ \\
$P$-value & $30.26 \pm 6.56^{\mathrm{a}}$ & $47.0 \pm 13.03^{\mathrm{ab}}$ \\
Season & 0.04 & $<0.0001$ \\
Fall & & \\
Spring & $19.3 \pm 4.13$ & $61.5 \pm 6.81^{\mathrm{a}}$ \\
Summer & $20.7 \pm 4.03$ & $50.1 \pm 6.43^{\mathrm{b}}$ \\
Winter & $18.0 \pm 4.25$ & $63.5 \pm 6.85^{\mathrm{a}}$ \\
$P$-value & $16.2 \pm 4.12$ & $46.6 \pm 6.56^{\mathrm{b}}$ \\
Health status & 0.14 & $<0.0001$ \\
KET & & \\
KET+ & $20.6 \pm 4.15^{\mathrm{a}}$ & $69.0 \pm 7.33$ \\
ND & $23.5 \pm 4.90^{\mathrm{a}}$ & $50.9 \pm 8.82$ \\
SICK & $11.8 \pm 3.94^{\mathrm{b}}$ & $68.5 \pm 6.62$ \\
$P$-value & $18.4 \pm 3.23^{\mathrm{a}}$ & $65.1 \pm 7.24$ \\
\hline
\end{tabular}

${ }^{\mathrm{a}, \mathrm{b}}$ Means within the same column with different superscript letters are significantly different.

${ }^{1}$ Cyclicity at 42 DIM was defined as the presence of a corpus luteum by ultrasound at $28 \pm 3$ or $42 \pm 3$ DIM. LSM \pm SEM are presented.

${ }^{2} \mathrm{KET}=$ cows that experienced only ketosis; KET $+=$ cows that experienced ketosis and at least another health condition within $30 \mathrm{DIM}$ $\mathrm{ND}=$ nondiseased cows; and SICK $=$ cows experiencing any disease other than ketosis during the study period.

and decreased probability of pregnancy up to 300 DIM compared with ND cows.

Mean LT during early lactation (2 wk after calving) did not have a significant effect on milk yield. Similarly, Steensels et al. (2012) found no correlation between LT and milk yield during early lactation. However, other authors have suggested a positive correlation of milk yield and LT of mid-lactation cows (Grant, 2007). Perhaps the increased milk yield reported in the later study could be due to the stage of lactation (cows in mid lactation) or the lack of the analytical control of the confounding effect of parity. Multiparous cows had greater LT and milk yield compared with primiparous cows (Steensels et al., 2012); thus, the parity effect has to be accounted for in the model. Conversely, Norring et al. (2012) suggested a negative correlation of milk yield with LT of lactating cows in wk 8 of lactation. Because lactating cows in the later study might have been close to the peak of lactation, greater DMI compared with cows in early postpartum would be expected. Therefore, it would be reasonable that high-producing cows would spend more time eating instead of lying down. However, in our study, lactating cows from 0 to 14 DIM would have a reduced DMI compared with cows at their peak of lactation and thus mobilize more body reserves to 
support lactation. Therefore, it could be proposed that no correlation exists between milk yield and LT early in lactation. This might be partly explained by the increased mobilization of body reserves early in lactation to support milk production, which could compensate for any disturbance in lying time.

Interestingly, in the present study, the CV of LT during the first 14 DIM had a weak negative correlation with milk yield at first DHIA test $(\mathrm{r}=-0.16)$. To the best of our knowledge, this is the first study that assessed the association of the CV of LT with milk yield. The consistency of daily LT by assessing the CV could provide valuable information about lactating cow performance rather than merely evaluating weekly LT means. Alterations in feed bunk management (e.g., feed availability), stall and lying surface maintenance (e.g., bedding frequency and DM; Tucker et al., 2004; Drissler et al., 2005), regrouping animals and stocking density (Huzzey et al., 2006; von Keyserlingk et al., 2008), cattle restraints for health screening (Cooper et al., 2007), and heat stress (Cook et al., 2007) might all have a detrimental effect on LT. However, changes in management factors or weather conditions that may alter LT patterns may be masked when assessing the mean LT due to behavioral compensations. The CV could identify these daily changes and reveal the LT inconsistency due to management or environment as opposed to assessing the mean LT behavior where this effect could be masked. It has been shown that cows compensate for their loss in LT after a period of deprivation (Metz, 1985). For instance, dairy cows experiencing deprived LT on any given day (e.g., $6 \mathrm{~h} / \mathrm{d}$ due to wet bedding) will likely compensate the following day by increasing LT $(14 \mathrm{~h} / \mathrm{d})$. Because the CV is obtained as the ratio of the standard deviation to the LT mean (e.g., 7 consecutive days) and reported as an absolute value $(\mathrm{CV}=\mathrm{SD} /$ mean $\mathrm{LT})$, a cow experiencing inconsistent management could have a $\mathrm{CV}$ of 0.30 (or 30\%), whereas another cow under consistent management could have a CV of 0.07 (or $7 \%$ ), while both cows have similar mean LT of $12 \mathrm{~h} / \mathrm{d}$. Further research is needed to assess the effect of management practices or environmental conditions on the CV of LT of cows and its implications on survival, health, and performance.

The association of LT with culling within 60 DIM is opposite to what was initially hypothesized. Increased LT during the first 14 DIM was associated with increased risk of culling within 60 DIM. Although lying is a strong behavioral need (Munksgaard et al., 2005), the behavior of ND during early lactation is characterized by a decrease of 1 to $2 \mathrm{~h} / \mathrm{d}$ in LT compared with the prepartum period (Maselyne et al., 2017). These changes in LT could be explained, at least in part, by time spent in the parlor, increased competition for stalls due to regrouping, increased restraint time of animals for health screenings early in lactation, increased feeding time driven by the increased nutrient demands to support milk production shortly after calving, or a combination of these. Cows experiencing ketosis and other health

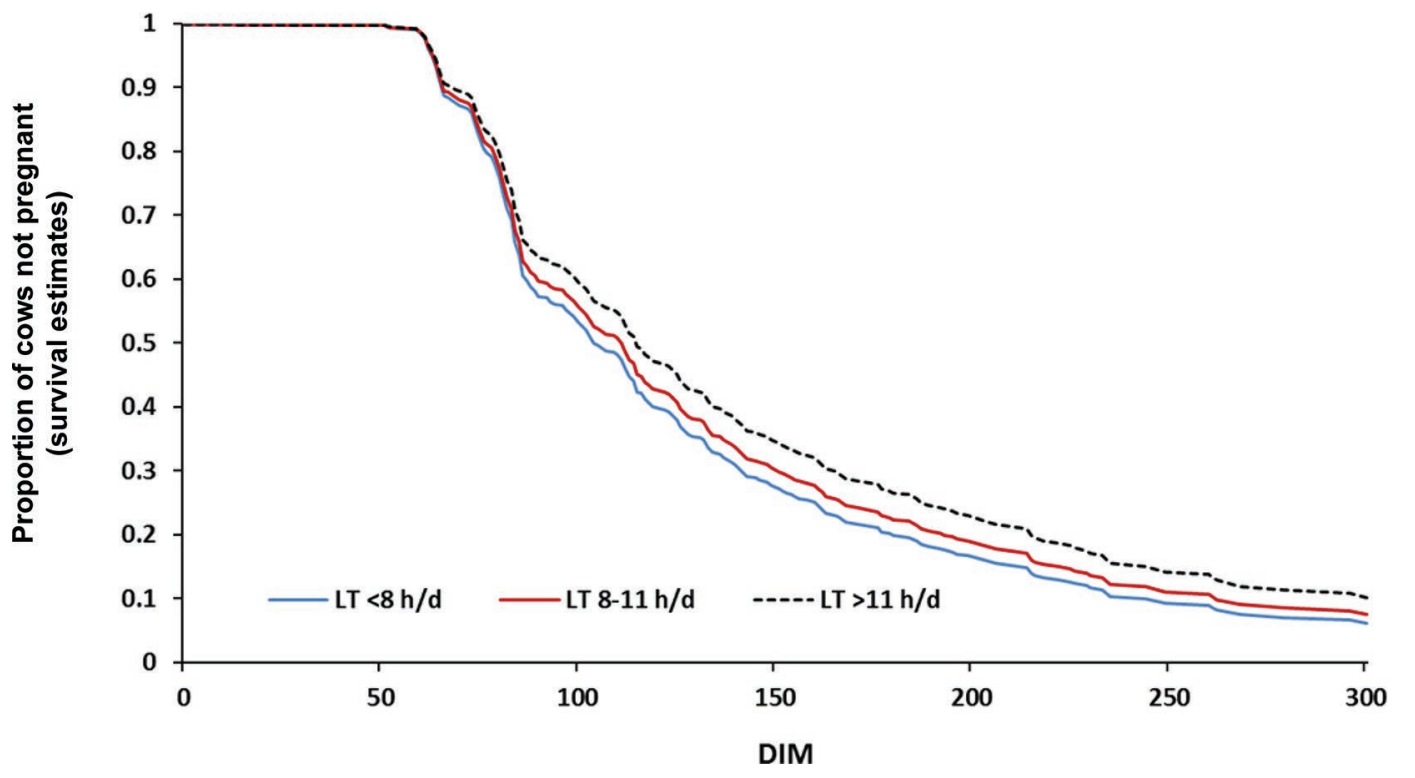

Figure 4. Survival curves for time to pregnancy of primiparous Holstein cows $(\mathrm{n}=390)$ grouped by mean lying time (LT) during the first 14 DIM. Grouping was defined using the mean LT during 0 to 14 DIM ( \pm 1 SD) of nondiseased primiparous cows as reference values (8-11 h/d), and cows with LT above $(>11 \mathrm{~h} / \mathrm{d})$ or below $(<8 \mathrm{~h} / \mathrm{d})$ those reference values. Adjusted hazard ratios $($ AHR; $95 \% \mathrm{CI})$ for pregnancy $(P=0.62)$ were $0.89(0.63-1.24)$ and $1.08(0.81-1.43)$ for cows with $\mathrm{LT}>11 \mathrm{~h} / \mathrm{d}$ and $<8 \mathrm{~h} / \mathrm{d}$, respectively. 


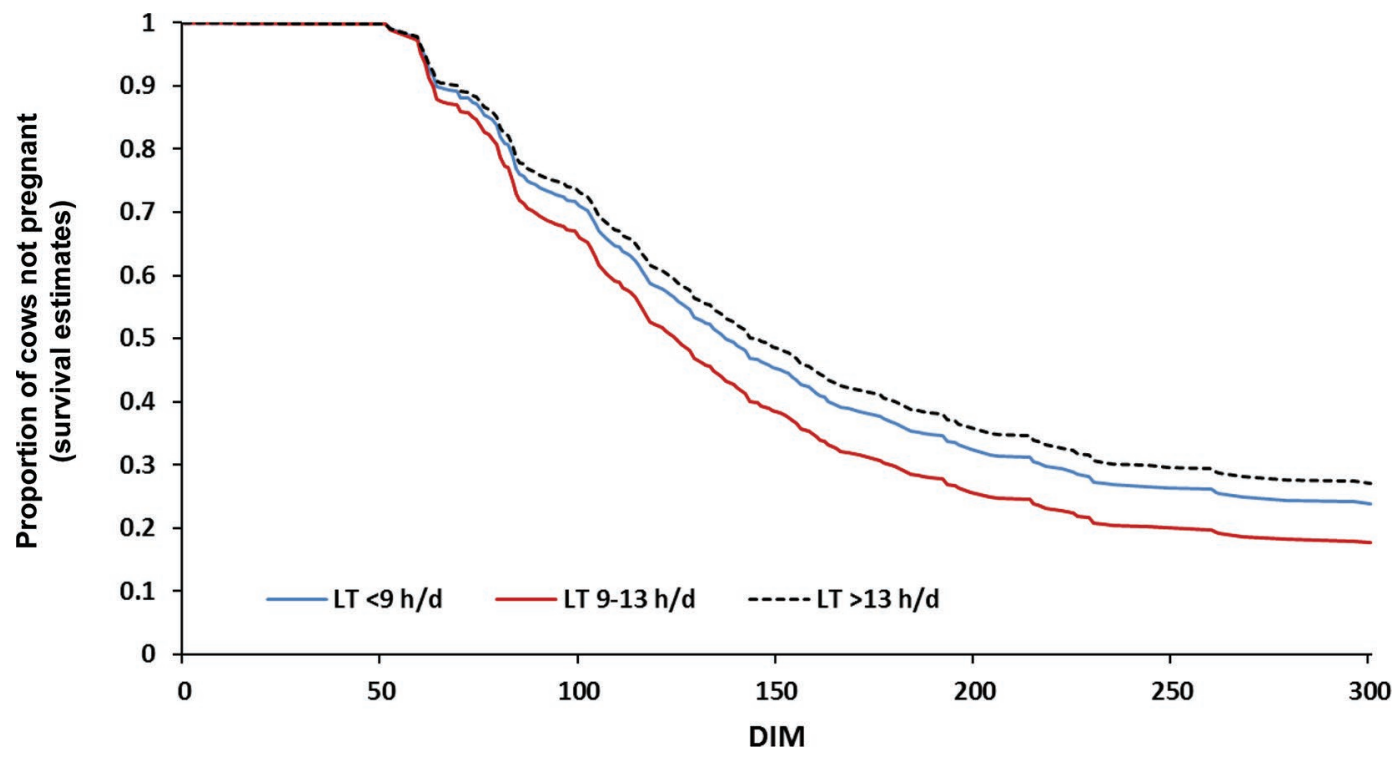

Figure 5. Survival curves for time to pregnancy of multiparous $(\mathrm{n}=634)$ Holstein cows grouped by mean lying time (LT) during the first 14 DIM. Grouping was defined using the mean LT during 0 to 14 DIM ( $\pm 1 \mathrm{SD})$ of nondiseased multiparous cows as reference values (9-13 h/d), and cows with LT above $(>13 \mathrm{~h} / \mathrm{d})$ or below $(<9 \mathrm{~h} / \mathrm{d})$ the reference values. Adjusted hazard ratios $(\mathrm{AHR} ; 95 \% \mathrm{CI})$ for pregnancy $(P=0.05)$ were $0.76(0.59-0.97 ; P=0.02)$ and $0.83(0.63-1.10 ; P=0.18)$ for cows with $\mathrm{LT}>13 \mathrm{~h} / \mathrm{d}$ and $<8.5 \mathrm{~h} / \mathrm{d}$, respectively.

events $(\mathrm{KET}+$ cows $)$ deviate from this normal behavior and have greater LT during the first week after calving compared with ND cows (Kaufman et al., 2016). Lactating cows with increased LT may have a dystocic birth at calving, which could have increased the risk of disease (e.g., metritis) and risk of culling within 60 DIM (Beaudeau et al., 2000). Barragan et al. (2017) showed that lactating cows that experienced dystocia had greater LT than cows with eutocic births $(9.8 \pm 0.3$ h/d vs. $8.5 \pm 0.3 \mathrm{~h} / \mathrm{d}$, respectively). Notably, KET+ cows had greater LT than ND cows and the highest proportion of cows with dystocia (15\%) compared with the other health groups. Alternatively, these lactating cows might have had a chronic disease that flared up at calving or an infectious disease occurring shortly after. The risk for IMI greatly increases during the last phase of the dry period during colostrogenesis because of the loss of the teat keratin plug ( 7 to $10 \mathrm{~d}$ before parturition; Cousins et al., 1980), dilution of protective factors (e.g., lactoferrin), and impaired leukocyte function (Bradley and Green, 2004). These diseases or other health events (e.g., lameness) might have increased LT during the first 14 DIM; thus, increasing the risk of culling within 60 DIM.

The highest and lowest points in the quadratic curve of LT during 0 to 14 DIM by CYC were reached when lactating cows had an LT of 10 to $11 \mathrm{~h} / \mathrm{d}$ and an LT of $>15 \mathrm{~h} / \mathrm{d}$, respectively (Figure 3). Considering that lactating cows were milked 3 times daily, which represents about 2.5 to $3 \mathrm{~h} / \mathrm{d}$ at the parlor, cows with $\mathrm{LT}>15 \mathrm{~h} / \mathrm{d}$ would have less than $6 \mathrm{~h}$ to allocate other important behaviors such as feeding, socializing, or drinking water (Gomez and Cook, 2010). Therefore, these lactating cows likely had more time away from the feed bunk, which could result in reduced feeding time, reduced DMI, and an exacerbated negative energy balance (NEB). Although health status was included in the model to account for the confounding effect of diseases, some cows could have experienced unmeasured health events responsible for their increased LT and increased energy demands, resulting in the observed detrimental effect on cyclicity.

Multiparous KET+, KET, and SICK cows had greater LT during the first week after calving and greater BCS loss compared with multiparous ND cows (Piñeiro et al., 2019). Moreover, the most frequently diagnosed disease in KET + and SICK cows was metritis (71 and $76 \%$ of cows diagnosed with metritis, respectively). The increased BCS loss and risk of ketosis and metritis in cows with increased LT shortly after calving might partially explain the reduced cyclicity in cows resting $>15 \mathrm{~h} / \mathrm{d}$. Uterine infections are commonly associated with Trueperella pyogenes and gram-negative bacteria (Escherichia coli, Fusobacterium necrophorum, and Prevotella spp.; Sheldon, 2004). Severe inflammation as a result of gram-negative bacterial infections leads to increased concentrations of LPS in plasma and follicular fluids (Herath et al., 2007, 2009). In turn, LPS decreases the release of $\mathrm{GnRH}$ and $\mathrm{LH}$ and activity of aromatase, resulting in decrease follicular growth and 


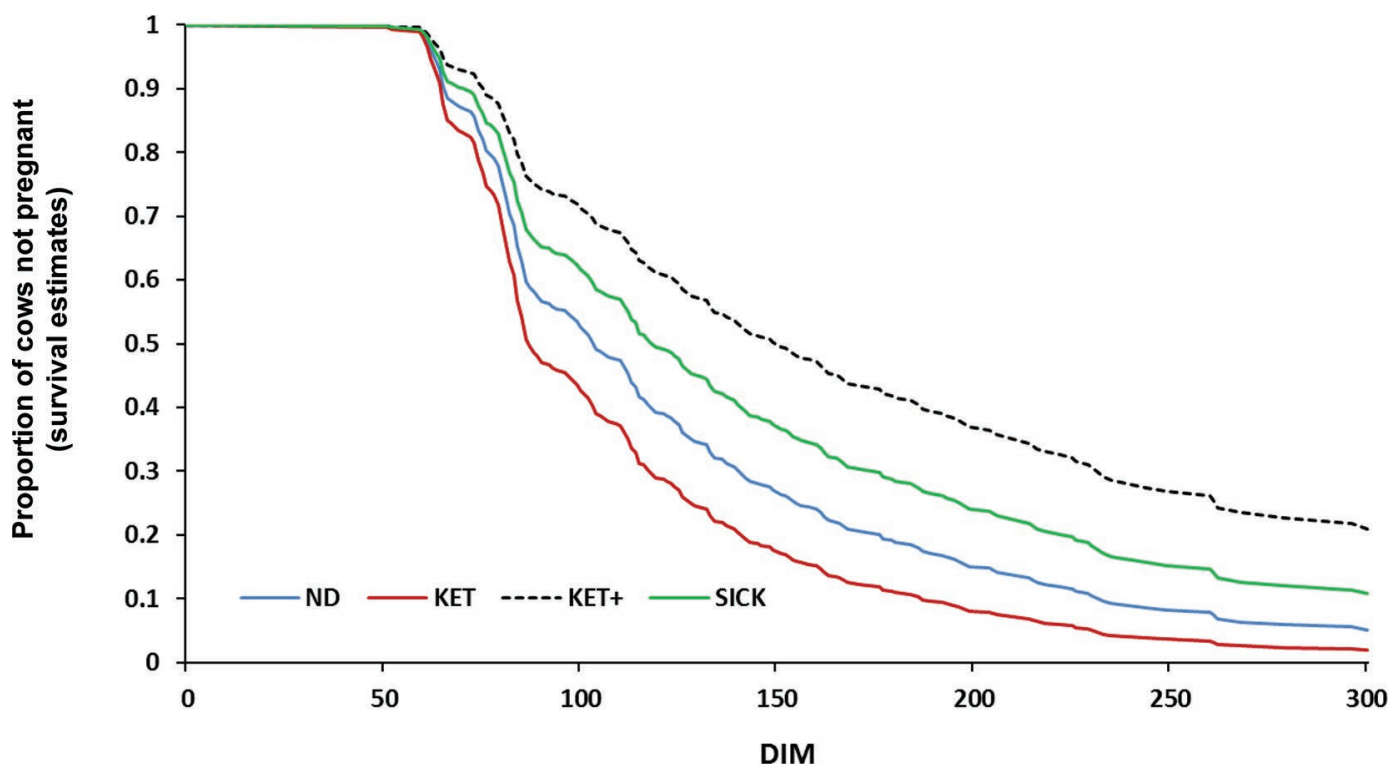

Figure 6. Survival curves for time to pregnancy of primiparous Holstein cows grouped by health status. Primiparous dairy cows $(\mathrm{n}=390)$ were classified in 1 of 4 groups based on their health status within 30 DIM: ND = nondiseased cows (referent); KET = cows that experienced only ketosis; KET $+=$ cows that experienced ketosis and at least another health condition within 30 DIM; and SICK $=$ cows experiencing any disease other than ketosis. Adjusted hazard ratios (AHR; 95\% CI) for pregnancy $(P<0.007)$ were $0.53(0.31-0.91 ; P=0.02), 0.75(0.59-0.97$; $P=0.02)$ and $1.32(0.85-2.06 ; P=0.21)$ for KET + , SICK, and KET cows, respectively.

decreased production of estradiol (Herath et al., 2009), which would be detrimental for cyclicity. Vercouteren et al. (2015) showed that lactating dairy cows that lost more than $28 \mathrm{~kg}$ of $\mathrm{BW}$ within the first 2 wk after calving, or experienced metabolic diseases, metritis, or digestive problems were associated with reduced cyclicity. Severe NEB results in decrease cyclicity due to decreased blood glucose, insulin, IGF-1, and pulsatility of LH. In turn, the exacerbated NEB and decrease of these metabolites and hormones early in lactation impair follicular development, ovulation, cyclicity, and reproductive performance (Beam and Butler, 1999; Butler, 2003).

The decreased cyclicity of primiparous cows compared with cows in greater lactations has been previously reported and might be due to an increased susceptibility of the effects of NEB on the hypothalamus-pituitaryovarian axis controlling cyclicity (Santos et al., 2009; Vercouteren et al., 2015). All 3 farms formulated and fed prepartum, postpartum, and high-lactation diets. Because all lactating cows were commingled after calving, the feeding management strategy might have been unable to meet the nutritional requirements of firstlactation cows with the subsequent observed NEB and reduced cyclicity. The inability of primiparous cows to meet their energy requirement when commingled with multiparous cows could be attributed, at least in part, to the diet formulation, which is typically formulated for the average cow within the group or their lower hi- erarchical position, which could lead to decreased feed intake due to displacements at the feed bunk (Grant and Albright, 2001). The seasonal effect of increased cyclicity during fall and summer observed in the present study has been previously reported (Santos et al., 2009; Vercouteren et al., 2015). Other studies reported increased cyclicity of cows calving during fall and spring (Opsomer et al., 2000) or spring and summer (Dubuc et al., 2012), but not during winter. It is possible that photoperiod is affecting cows during fall and summer because melatonin decreases as day length increases and the secretion of melatonin suppresses IGF-1 (Dahl et al., 2000), which in turn increases estradiol production and follicle growth (Butler, 2003).

Multiparous cows lying $>13 \mathrm{~h}$ during the first 14 DIM had decreased probability of pregnancy up to 300 DIM compared with multiparous cows with LT of 9 to $13 \mathrm{~h} / \mathrm{d}$. This finding could be explained in part by the decreased cyclicity observed in cows with LT $>13 \mathrm{~h} / \mathrm{d}$, which may be experiencing one or more health events (Figure 3). Cyclicity early in lactation has been associated with improved reproductive performance (McCoy et al., 2006). Regardless of parity, lactating cows experiencing ketosis and at least another diagnosed disease during the first month after calving (KET+) had decreased probability of pregnancy up to 300 DIM compared with ND cows. This effect may be partly explained by the tendency $(P=0.06)$ observed in KET+ cows with decreased cyclicity at 42 DIM compared with 
ND cows (Table 2). Severe inflammation and deep NEB during the early postpartum period negatively affects cyclicity of lactating dairy cows (Dubuc et al., 2012). Cows diagnosed with ketosis and other diseases (e.g., metritis, mastitis) have increased LT during the first week after calving compared with cows with no diagnoseds adverse health event (Kaufman et al., 2016). Uterine infections with recognized pathogens (Williams et al., 2005) and other gram-negative bacterial infections lead to increased concentrations of LPS in plasma and follicular fluids (Herath et al., 2007, 2009). In turn, LPS inhibits the release of GnRH and LH and aromatase activity within ovarian follicles, resulting in decreased follicular growth and decreased blood estradiol (Williams et al., 2007; Herath et al., 2009). Moreover, cows diagnosed with infectious diseases (e.g., metritis) early in lactation typically have increased serum concentrations of haptoglobin compared with nondiseased cows (Stangaferro et al., 2016a,b,c; Barragan et al., 2018). Dubuc et al. (2012) showed that cycling lactating cows at 21 DIM had reduced serum concentrations of haptoglobin for the first $3 \mathrm{wk}$ after calving compared with anovular cows at 21,35, 49, or 63 DIM.

Regardless of parity, ND lactating cows produced more milk at first DHIA test than KET + cows. In addition, primiparous ND and KET lactating cows produced more milk at first DHIA test than KET + and SICK cows. The detrimental effects of ketosis and infectious diseases (e.g., metritis, mastitis) on milk yield have been reported previously (Fourichon et al., 1999; Dubuc et al., 2011; McArt et al., 2012a). This reduction in milk yield might occur due to the combined effect of a reduction in DMI of lactating cows experiencing diseases and the increased glucose consumption because of an acute response from the immune system. Previous studies showed that lactating dairy cows that had metritis consume between 2 to $6 \mathrm{~kg}$ of DM/d less during early lactation (Huzzey et al., 2007) and had increased blood concentration of haptoglobin (Huzzey et al., 2009). Haptoglobin is an acute phase protein produced in the liver that increases in the event of acute response of the immune system. In addition, postpartum cows that experience retained placenta (Pohl et al., 2015) or mastitis (Stangaferro et al., 2016b) have high serum haptoglobin concentrations during early lactation compared with healthy cows. Acute immune responses due to bacterial infections (e.g., E. coli) greatly increase glucose utilization by the immune system, thus resulting in decrease milk yield (Kvidera et al., 2017).

Typically, cows experiencing ketosis and other concomitant diseases would have increased concentration of serum haptoglobin compared with nondiseased cows, as observed by Stangaferro et al. $(2016 \mathrm{a}, \mathrm{b}, \mathrm{c})$ and Piñeiro et al. (2019). This corresponds with the observed decrease in milk yield in KET+ compared with ND lactating cows. Acute inflammation response (increased haptoglobin and decreased neutrophil count) associated with infectious diseases, or metabolic and infectious

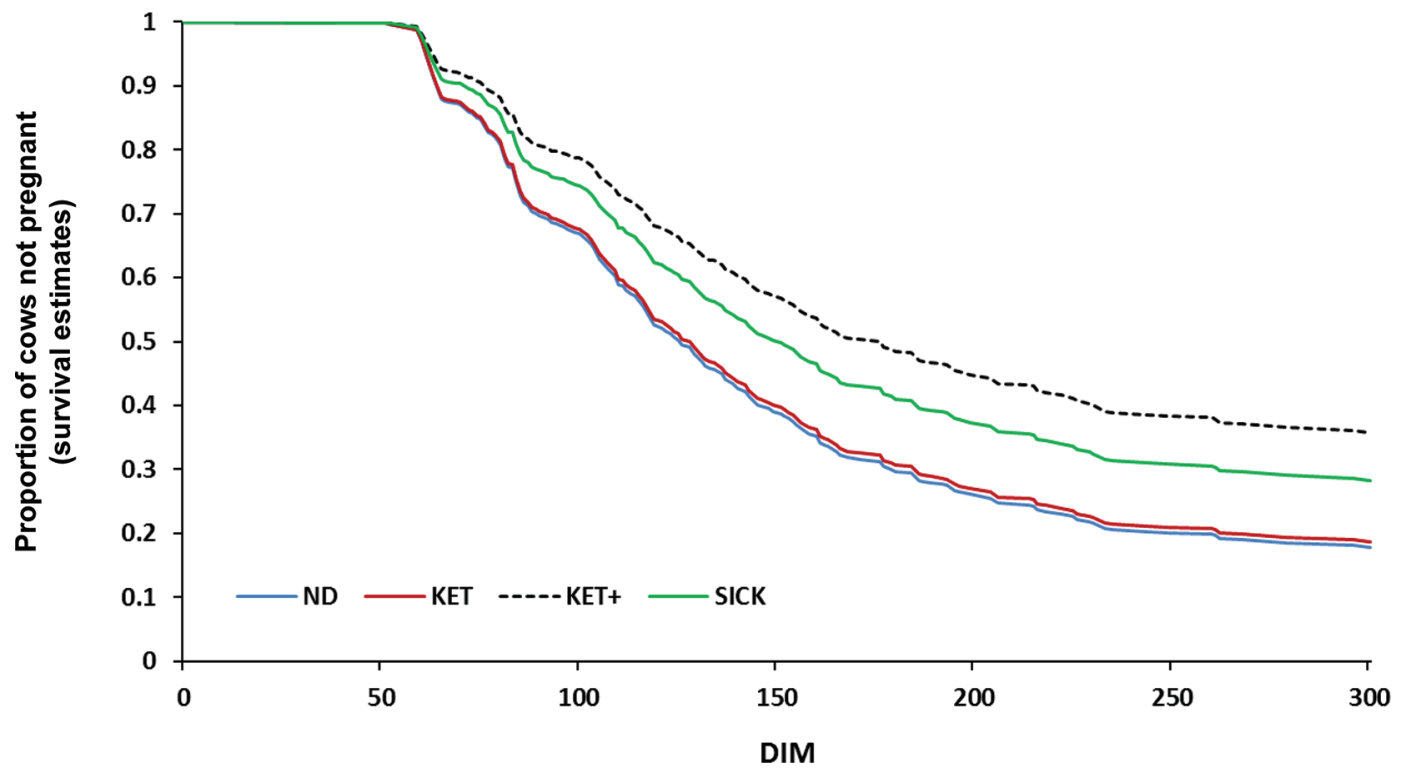

Figure 7. Survival curves for time to pregnancy of multiparous Holstein cows grouped by health status. Multiparous dairy cows (n $=633$ ) were classified in 1 of 4 groups based on their health status within 30 DIM: ND = nondiseased cows (referent); KET = cows that experienced only ketosis; KET $+=$ cows that experienced ketosis and at least another health condition within 30 DIM; and SICK = cows experiencing any disease other than ketosis. Adjusted hazard ratios (AHR; 95\% CI) for pregnancy $(P=0.02)$ were $0.60(0.38-0.93 ; P=0.02), 0.73(0.55-0.98 ; P$ $=0.03)$ and $0.97(0.77-1.23 ; P=0.82)$ for KET + , SICK, and KET cows, respectively. 
diseases combined, could have negatively affected milk yield. However, lactating cows in KET did not differ from ND cows in terms of milk production or reproductive performance. These results suggest that KET cases without another concomitant metabolic or infectious disease during early lactation might not have a detrimental effect on milk yield and reproductive performance. However, these results do not reflect the direct effect of ketosis on milk yield of lactating cows. To assess the effect of ketosis on milk yield, a valid approach is to control the variables preceding the exposure factor that could act as confounders but not analytically control the intervening variables occurring after the exposure factor (e.g., metritis, mastitis; Dohoo et al., 2009). McArt et al. (2012b) found that cows experiencing subclinical ketosis produced $0.5 \mathrm{~kg} / \mathrm{d}$ less milk for the first 30 DIM for each $0.1 \mathrm{mmol} / \mathrm{L}$ increase in BHB at the first positive test. Jawor et al. (2012) showed that after controlling for the effect of other transition diseases (e.g., metritis, mastitis), cows with subclinical hypocalcemia within $24 \mathrm{~h}$ after parturition produced, on average, $5.7 \mathrm{~kg}$ more milk in wk 2,3 , and 4 than cows that did not have hypocalcemia. Similarly, cases of ketosis that are not complicated with other diseases early in lactation seem to not have a detrimental effect on milk yield and reproductive performance.

Compared with ND cows, SICK, KET, and KET+ cows had higher risk of being culled within 60 DIM. The effect of ketosis or other metabolic diseases and infectious diseases (e.g., metritis, mastitis) have been previously reported (Rajala-Schultz and Gröhn, 1999; Beaudeau et al., 2000). Cows that presented ketosis, displaced abomasum, or metritis within 30 DIM are 2.0, 6.8, and 2.5 times more likely to be culled during the first month of lactation (Rajala-Schultz and Gröhn, 1999). Conversely to what we initially hypothesized, lactating cows with increased LT during the first 14 DIM had increased risk of culling within 60 DIM and decreased cyclicity and reproductive performance, which may be due to the observed NEB and other concomitant infectious diseases (Piñeiro et al., 2019). A possible limitation of this study is that the health screening of postpartum cows (e.g., retained fetal membranes, mastitis, displaced abomasum) was performed by farm personnel, whereas only metritis, ketosis, and locomotion and body condition scores were assessed by our research team. Although disease diagnosis was performed by trained farm personnel, the frequency of screening and accuracy of diagnosis were not strictly controlled by the researchers. Therefore, it is likely that diseases such as pneumonia or mastitis were underdiagnosed in the present study. In addition, due to the sampling scheme, some cases of metritis could have occurred after clinical examination and some cases of ketosis could have occurred and resolved between the first and second blood samples. Although there is a possibility of potential misclassification biases, lactating cows diagnosed and classified as KET, KET+ or SICK had similar performance (e.g., milk yield, culling, cyclicity, and reproductive performance) as previously reported (Rajala-Schultz et al., 1999; Beaudeau et al., 2000).

Lying time could be used as an indicator of appropriate heat abatement (Cook et al., 2007), facility design and maintenance (Tucker et al., 2004; Drissler et al., 2005), and management practices (Cooper et al., 2007). However, LT should be assessed with caution during the early postpartum period when most health events occur (LeBlanc et al., 2006) because increased LT is also an indicator of cows experiencing diseases. To overcome this complexity, other precision technologies such as rumination time could be used simultaneously. A recent study has shown that decreased rumination time could be used to flag, with high sensitivity, lactating cows before they experience metabolic or digestive disorders (Stangaferro et al., 2016a). In addition, it was shown that dairy cows during early $(40 \pm 9$ DIM $)$ and late lactation (276 \pm 49 DIM) had approximately 12 h/d of lying time (Munksgaard et al., 2005), whereas early postpartum cows had 1 to $2 \mathrm{~h}$ less compared with mid-lactation cows (Maselyne et al., 2017). However, there is scant information in the literature about the behavioral need of LT for dairy cows in the early postpartum period. Results from our study suggest that during the first 14 DIM, the optimum lying time, in terms of reproductive performance, for multiparous cows ranges from 9 to $13 \mathrm{~h} / \mathrm{d}$. Further research is needed to determine the optimum LT of dairy cows during the early postpartum period, taking into account housing facilities and management practices.

\section{CONCLUSIONS}

The results from this study suggest that milk yield early in lactation was not correlated with mean LT but had a weak negative correlation with the CV of LT during the first 14 DIM. In addition, LT early in lactation had a positive linear association with CULL and a negative quadratic association with CYC. Additionally, both infectious and metabolic diseases decreased milk yield and the probability of pregnancy up to 300 DIM. Furthermore, multiparous lactating cows housed in freestall barns had an optimum range of 9 to $13 \mathrm{~h} / \mathrm{d}$ of LT during 0 to 14 DIM, in which reproductive performance was maximized. These findings suggest that there is an optimum daily LT range for early postpartum dairy cows housed in freestall barns, which is different from that reported for mid-lactation cows, with 
the potential for improved survival, health, resumption of cyclicity, and subsequent overall performance.

\section{ACKNOWLEDGMENTS}

Collaborating dairy farms and their staff are greatly appreciated for providing the animals used in this study; we are also grateful to graduate and undergraduate students for their assistance during the project. Also, the laboratory support from D. J. Wyatt (The Ohio State University, Wooster) and D. Mollenkopf (The Ohio State University, Columbus) as well as the valuable suggestions from Greg Habing and Luciana da Costa (The Ohio State University, Columbus) are greatly appreciated. This project was partially supported by Veterinary Extension at The Ohio State University, College of Veterinary Medicine.

\section{REFERENCES}

Allen, J. D., L. W. Hall, R. J. Collier, and J. F. Smith. 2015. Effect of core body temperature, time of day, and climate conditions on behavioral patterns of lactating dairy cows experiencing mild to moderate heat stress. J. Dairy Sci. 98:118-127.

Bach, A., M. Dinarés, M. Devant, and X. Carré. 2007. Associations between lameness and production, feeding and milking attendance of Holstein cows milked with an automatic milking system. J. Dairy Res. 74:40-46.

Barragan, A. A., L. M. Bauman, L. da Costa, J. Velez, J. D. Rozo Gonzalez, G. M. Schuenemann, and S. Bas. 2017. Effects of oral administration of acetylsalicylic acid after parturition on milk yield and milk components in lactating dairy cows under certified organic management. J. Dairy Sci. 100 (Suppl. 1):17. (Abstr.)

Barragan, A. A., J. M. Piñeiro, G. M. Schuenemann, P. J. RajalaSchultz, D. E. Sanders, J. Lakritz, and S. Bas. 2018. Assessment of daily activity patterns and biomarkers of pain, inflammation, and stress in lactating dairy cows diagnosed with clinical metritis. J. Dairy Sci. 101:8248-8258.

Beam, S. W., and W. R. Butler. 1999. Effects of energy balance on follicular development and first ovulation in postpartum dairy cows. J. Reprod. Fertil. Suppl. 54:411-424.

Beaudeau, F., H. Seegers, V. Ducrocq, C. Fourichon, and N. Bareille. 2000. Effect of health disorders on culling in dairy cows: A review and a critical discussion. Ann. Zootech. 49:293-311.

Boichard, D. 1990. Estimation of the economic value of conception rate in dairy cattle. Livest. Prod. Sci. 24:187-204.

Bradley, A. J., and M. J. Green. 2004. The importance of the nonlactating period in the epidemiology of intramammary infection and strategies for prevention. Vet. Clin. North Am. Food Anim. Pract. 20:547-568.

Butler, W. R. 2003. Energy balance relationships with follicular development, ovulation and fertility in postpartum dairy cows. Livest. Prod. Sci. 83:211-218.

Chapinal, N., A. M. de Passillé, D. M. Weary, M. A. G. von Keyserlingk, and J. Rushen. 2009. Using gait score, walking speed, and lying behavior to detect hoof lesions in dairy cows. J. Dairy Sci. 92:4365-4374.

Cook, N. B., R. L. Mentink, T. B. Bennett, and K. Burgi. 2007. The effect of heat stress and lameness on time budgets of lactating dairy cows. J. Dairy Sci. 90:1674-1682.

Cooper, M. D., D. R. Arney, and C. J. C. Phillips. 2007. Two- or fourhour lying deprivation on the behavior of lactating dairy cows. J. Dairy Sci. 90:1149-1158.
Cousins, C. L., T. M. Higgs, E. R. Jackson, F. K. Neave, and F. H. Dodd. 1980. Susceptibility of the bovine udder to bacterial infection in the dry period. J. Dairy Res. 47:11-18.

Dahl, G. E., B. A. Buchanan, and H. A. Tucker. 2000. Photoperiodic effects on dairy cattle: A review. J. Dairy Sci. 83:885-893.

De Vries, A. 2013. Cow longevity economics: The cost benefit of keeping the cow in the herd. Pages 22-52 in Proc. Cow Longevity Conf., Tumba, Sweden. DeLaval International AB, Tumba, Sweden.

Dohoo, I., W. Martin, and H. Stryhn. 2009. Introduction and causal concepts. Pages 21-23 in Veterinary Epidemiologic Research. 2nd ed. VER Inc., Charlottetown, PEI, Canada.

Drissler, M., M. Gaworski, C. B. Tucker, and D. M. Weary. 2005 Freestall maintenance: Effects on lying behavior of dairy cattle. J. Dairy Sci. 88:2381-2387.

Dubuc, J., T. F. Duffield, K. E. Leslie, J. S. Walton, and S. J. LeBlanc. 2011. Effects of postpartum uterine diseases on milk production and culling in dairy cows. J. Dairy Sci. 94:1339-1346.

Dubuc, J., T. F. Duffield, K. E. Leslie, J. S. Walton, and S. J. LeBlanc. 2012. Risk factors and effects of postpartum anovulation in dairy cows. J. Dairy Sci. 95:1845-1854.

Essl, A. 1998. Longevity in dairy cattle breeding: A review. Livest. Prod. Sci. 57:79-89.

Ferguson, J. D., D. T. Galligan, and N. Thomsen. 1994. Principal descriptors of body condition score in Holstein cows. J. Dairy Sci. 77:2695-2703.

Fetrow, J., K. V. Nordlund, and H. D. Norman. 2006. Invited Review: Culling: Nomenclature, definitions, and recommendations. J. Dairy Sci. 89:1896-1905.

Fourichon, C., H. Seegers, N. Bareille, and F. Beaudeau. 1999. Effects of disease on milk production in the dairy cow: A review. Prev. Vet. Med. 41:1-35.

Fregonesi, J. A., and J. D. Leaver. 2001. Behaviour, performance and health indicators of welfare for dairy cows housed in strawyard or cubicle systems. Livest. Prod. Sci. 68:205-216.

Galindo, F., and D. M. Broom. 2000. The relationships between social behaviour of dairy cows and the occurrence of lameness in three herds. Res. Vet. Sci. 69:75-79.

Gomez, A., and N. B. Cook. 2010. Time budgets of lactating dairy cattle in commercial freestall herds. J. Dairy Sci. 93:5772-5781.

Grant, R. 2007. Taking advantage of natural behavior improves dairy cow performance. Pages 225-236 in Proc. Western Dairy Manage. Conf., Reno, NV. Kansas State University, Manhattan.

Grant, R. J., and J. L. Albright. 2001. Effect of animal grouping on feeding behavior and intake of dairy cattle. J. Dairy Sci. 84:E156E163

Hasegawa, N., Y. Syuji, K. Matoba, and K. Sugawara. 1993. Behavior of high-producing dairy cattle in tie stall barn. Anim. Sci. Technol. (Jpn.) 64:709-718.

Herath, S., S. T. Lilly, D. P. Fischer, E. J. Williams, H. Dobson, C. E. Bryant, and I. M. Sheldon. 2009. Bacterial lipopolysaccharide induces an endocrine switch from prostaglandin F2 $\alpha$ to prostaglandin E2 in bovine endometrium. Endocrinology 150:1912-1920.

Herath, S., E. J. Williams, S. T. Lilly, R. O. Gilbert, H. Dobson, C. E. Bryant, and I. M. Sheldon. 2007. Ovarian follicular cells have innate immune capabilities that modulate their endocrine function. Reproduction 134:683-693.

Huzzey, J. M., T. J. DeVries, P. Valois, and M. A. G. von Keyserlingk. 2006. Stocking density and feed barrier design affect the feeding and social behavior of dairy cattle. J. Dairy Sci. 89:126-133.

Huzzey, J. M., T. F. Duffield, S. J. LeBlanc, D. M. Veira, D. M. Weary, and M. A. G. von Keyserlingk. 2009. Short communication: Haptoglobin as an early indicator of metritis. J. Dairy Sci. 92:621-625.

Huzzey, J. M., D. M. Veira, D. M. Weary, and M. A. G. von Keyserlingk. 2007. Prepartum behavior and dry matter intake identify dairy cows at risk for metritis. J. Dairy Sci. 90:3220-3233.

Jawor, P. E., J. M. Huzzey, S. J. LeBlanc, and M. A. G. von Keyserlingk. 2012. Associations of subclinical hypocalcemia at calving with milk yield, and feeding, drinking, and standing behaviors around parturition in Holstein cows. J. Dairy Sci. 95:1240-1248. 
Kaufman, E. I., S. J. LeBlanc, B. W. McBride, T. F. Duffield, and T. J. DeVries. 2016. Association of rumination time with subclinical ketosis in transition dairy cows. J. Dairy Sci. 99:5604-5618.

Krawczel, P. D., L. B. Klaiber, R. E. Butzler, L. M. Klaiber, H. M. Dann, C. S. Mooney, and R. J. Grant. 2012. Short-term increases in stocking density affect the lying and social behavior, but not the productivity, of lactating Holstein dairy cows. J. Dairy Sci. 95:4298-4308.

Kvidera, S. K., E. A. Horst, M. Abuajamieh, E. J. Mayorga, M. V. Sanz Fernandez, and L. H. Baumgard. 2017. Glucose requirements of an activated immune system in lactating Holstein cows. J. Dairy Sci. 100:2360-2374.

LeBlanc, S. J., K. D. Lissemore, D. F. Kelton, T. F. Duffield, and K. E. Leslie. 2006. Major Advances in Disease Prevention in Dairy Cattle. J. Dairy Sci. 89:1267-1279.

Maselyne, J., M. Pastell, P. T. Thomsen, V. M. Thorup, L. Hänninen, J. Vangeyte, A. Van Nuffel, and L. Munksgaard. 2017. Daily lying time, motion index and step frequency in dairy cows change throughout lactation. Res. Vet. Sci. 110:1-3.

McArt, J. A. A., D. V. Nydam, and G. R. Oetzel. 2012a. A field trial on the effect of propylene glycol on displaced abomasum, removal from herd, and reproduction in fresh cows diagnosed with subclínical ketosis. J. Dairy Sci. 95:2505-2512.

McArt, J. A. A., D. V. Nydam, and G. R. Oetzel. 2012b. Epidemiology of subclinical ketosis in early lactation dairy cattle. J. Dairy Sci. 95:5056-5066.

McCoy, M. A., S. D. Lennox, C. S. Mayne, W. J. McCaughey, H. W. J. Edgar, D. C. Catney, M. Verner, D. R. Mackey, and A. W. Gordon. 2006. Milk progesterone profiles and their relationship with fertility, production and disease in dairy cows in Northern Ireland. Anim. Sci. 82:213-222.

Metz, J. H. M. 1985. The reaction of cows to a short-term deprivation of lying. Appl. Anim. Behav. Sci. 13:301-307.

Munksgaard, L., M. B. Jensen, L. J. Pedersen, S. W. Hansen, and L. Matthews. 2005. Quantifying behavioural priorities - effects of time constraints on behaviour of dairy cows, Bos taurus. Appl. Anim. Behav. Sci. 92:3-14.

Munksgaard, L., and H. B. Simonsen. 1996. Behavioral and pituitary adrenal-axis responses of dairy cows to social isolation and deprivation of lying down. J. Anim. Sci. 74:769-778.

National Research Council. 2001. Nutrient Requirements of Dairy Cattle. 7th rev. ed. National Academy Press, Washington, DC.

Norring, M., A. Valros, and L. Munksgaard. 2012. Milk yield affects time budget of dairy cows in tie-stalls. J. Dairy Sci. 95:102-108.

Opsomer, G., Y. T. Gröhn, J. Hertl, M. Coryn, H. Deluyker, and A. de Kruif. 2000. Risk factors for postpartum ovarian dysfunction in high producing dairy cows in Belgium: A field study. Theriogenology 53:841-857.

Pinedo, P. J., and A. De Vries. 2010. Effect of days to conception in the previous lactation on the risk of death and live culling around calving. J. Dairy Sci. 93:968-977.

Piñeiro, J. M., B. T. Menichetti, A. A. Barragan, W. P. Weiss, S. Bas, and G. M. Schuenemann. 2019. Associations of pre- and post-partum lying time with metabolic status, inflammation and health of dairy cows. J. Dairy Sci. 102:3348-3361. https://doi.org/10.3168/ jds.2018-15386.

Pohl, A., O. Burfeind, and W. Heuwieser. 2015. The associations between postpartum serum haptoglobin concentration and metabolic status, calving difficulties, retained fetal membranes, and metritis. J. Dairy Sci. 98:4544-4551.

Rajala-Schultz, P. J., and Y. T. Gröhn. 1999. Culling of dairy cows. Part I. Effects of diseases on culling in Finnish Ayrshire cows. Prev. Vet. Med. 41:195-208.
Rajala-Schultz, P. J., Y. T. Gröhn, and C. E. McCulloch. 1999. Effects of milk fever, ketosis, and lameness on milk yield in dairy cows. J. Dairy Sci. 82:288-294.

Santos, J. E. P., H. M. Rutigliano, and M. F. S. Filho. 2009. Risk factors for resumption of postpartum estrous cycles and embryonic survival in lactating dairy cows. Anim. Reprod. Sci. 110:207-221.

SAS Institute. 2014. SAS/STAT 9.2 User's Guide. 2nd ed. SAS Institute Inc., Cary, NC.

Schirmann, K., N. Chapinal, D. M. Weary, W. Heuwieser, and M. A. G. von Keyserlingk. 2012. Rumination and its relationship to feeding and lying behavior in Holstein dairy cows. J. Dairy Sci. 95:3212-3217.

Schuenemann, G. M., K. N. Galvão, S. Borchardt, W. Heuwieser, and P. Federico. 2017. Effect of culling rates on profitability of dairy herds achieving the same pregnancy rate. J. Dairy Sci. 100(Suppl.2):290. (Abstr.)

Sheldon, I. M. 2004. The postpartum uterus. Vet. Clin. North Am. Food Anim. Pract. 20:569-591.

Sheldon, I. M., G. S. Lewis, S. LeBlanc, and R. O. Gilbert. 2006. Defining postpartum uterine disease in cattle. Theriogenology 65:1516-1530.

Stangaferro, M. L., R. Wijma, L. S. Caixeta, M. A. Al-Abri, and J. O. Giordano. 2016a. Use of a rumination and activity monitoring for the identification of dairy cows with health disorders: Part I. Metabolic and digestive disorders. J. Dairy Sci. 99:7395-7410.

Stangaferro, M. L., R. Wijma, L. S. Caixeta, M. A. Al-Abri, and J. O. Giordano. 2016b. Use of rumination and activity monitoring for the identification of dairy cows with health disorders: Part II. Mastitis. J. Dairy Sci. 99:7411-7421.

Stangaferro, M. L., R. Wijma, L. S. Caixeta, M. A. Al-Abri, and J. O. Giordano. 2016c. Use of a rumination and activity monitoring for the identification of dairy cows with health disorders: Part III. Metritis. J. Dairy Sci. 99:7422-7433.

Steensels, M., C. Bahr, D. Berckmans, I. Halachmi, A. Antler, and E. Maltz. 2012. Lying patterns of high producing healthy dairy cows after calving in commercial herds as affected by age, environmental conditions and production. Appl. Anim. Behav. Sci. 136:88-95.

Tucker, C. B., D. M. Weary, and D. Fraser. 2004. Free-stall dimensions: Effects on preference and stall usage. J. Dairy Sci. 87:1208-1216.

Vercouteren, M. M., J. H. Bittar, P. J. Pinedo, C. A. Risco, J. E. P. Santos, A. Vieira-Neto, and K. N. Galvão. 2015. Factors associated with early cyclicity in postpartum dairy cows. J. Dairy Sci. 98:229-239.

Vieira-Neto, A., K. N. Galvão, W. W. Thatcher, and J. E. P. Santos. 2017. Association among gestation length and health, production, and reproduction in Holstein cows and implications for their offspring. J. Dairy Sci. 100:3166-3181.

von Keyserlingk, M. A. G., D. Olenick, and D. M. Weary. 2008. Acute behavioral effects of regrouping dairy cows. J. Dairy Sci. 91:10111016.

Walker, S. L., R. F. Smith, J. E. Routly, D. N. Jones, M. J. Morris, and H. Dobson. 2008. Lameness, activity time-budgets, and estrus expression in dairy cattle. J. Dairy Sci. 91:4552-4559.

Williams, E. J., D. P. Fischer, D. E. Noakes, G. C. W. England, A. Rycroft, H. Dobson, and I. M. Sheldon. 2007. The relationship between uterine pathogen growth density and ovarian function in the postpartum dairy cow. Theriogenology 68:549-559.

Williams, E. J., D. P. Fischer, D. U. Pfeiffer, G. C. W. England, D. E. Noakes, H. Dobson, and I. M. Sheldon. 2005. Clinical evaluation of postpartum vaginal mucus reflects uterine bacterial infection and the immune response in cattle. Theriogenology 63:102-117. 